\title{
Problems of Applying the Mechanism of Public-Private Partnership
}

\author{
Olga E. Astafyeva*, Natalia A. Moiseenko, Viktor M. Serov, Tatyana Yu. \\ Shemyakina
}

\begin{abstract}
Department of Economics and management in construction, State University of Management, Moscow, Russia
*Corresponding author. Email: oe_astafyeva@guu.ru
\end{abstract}

\begin{abstract}
The article is devoted to issues related to the problems that arise when implementing and evaluating the effectiveness of investment projects using the mechanism of Public-private partnership. The problem of using public-private partnership mechanisms in Russia is considered. The relevance of the chosen topic is confirmed by the need to create a well-developed mechanism for attracting private investors and companies to participate in public projects and programs. to develop and manage public infrastructures. The article considers approaches to the selection of PPP projects, lists the main limitations in the selection process, identifies and classifies the features of using PPP forms in relation to various factors, draws conclusions on the justification of a particular form of PPP, and gives some recommendations on project financing. The issues of ranking projects and considering schemes for effective implementation of such projects are discussed.

The article is structured in a way that affects the main stages of the project and its acceptance for funding, taking into account limitations in the choice of the project, the proposed selection algorithm, determining a sequence of projects, analyzed forms of PPP and financing models. The scientific novelty of the work consists in the proposed criteria for selecting projects for financing under PPP and in the methodology for ranking projects in the investment portfolio. In addition, the technical limitations and tasks of the sector, legal and regulatory restrictions, institutional problems and other special requirements of the sector, and the tasks of the government were analyzed, on the basis of which recommendations were made on the choice of a particular form of PPP. The proposed algorithm for evaluating PPP projects based on real options methods also deserves attention.
\end{abstract}

Keywords: public-private partnership, concession agreement, state order, efficiency, evaluation procedure, project selection

\section{INTRODUCTION}

During the global financial crisis, the role of the state increased dramatically in many countries, regardless of the type of economy. This is reflected in an increase in the volume of grants, subsidies and subventions from the state to private business, the development and implementation of a large number of socio-economic programs with the active participation of private business. In this regard, interest in public-private partnerships as an effective tool for state regulation of the economy [1, 2].

The mechanism of public-private partnership is widely used in the world and domestic practice to justify attracting private investment for long-term financing of public and social infrastructure facilities, including various areas of activity-transport, housing and utilities, healthcare, socially important facilities, etc. But to date, there is no single algorithm that regulates the procedure for implementing PPP projects, depending on the forms and types of projects, and the mechanisms for managing their implementation. There are lively discussions on this issue in the scientific and practical literature [3, 4].

The main goal of a PPP is to attract investment from private alternative sources to implement investment projects aimed at developing infrastructure of socially significant objects in the public interest by combining the resources and experience of each of the participating parties, with the lowest costs and risks.

Despite such a long history of its existence and extensive application, public-private partnerships do not, in our 
opinion, have any typical characteristics. The constant complication of legal forms, the emergence of new financial instruments, the development of technologies and scientific and technical progress in General significantly affect the way such projects are implemented. In this regard, we can formulate a number of important problems related to the functioning of publicprivate partnerships in the world economy, which arise in most countries.

The first major projects in the framework of cooperation between the state and private business appeared in the 18th century in the United States and were mainly associated with the construction of toll roads. Statistical studies of global trends over the past two years conducted by the UN and the IBRD show that road construction is still the most priority industry where the state and private business cooperate. For example, about 600 of the 915 projects of public-private partnerships (which were developed and implemented in the world as a whole) are related to the development of transport infrastructure (roads, bridges, interchanges). This is due to the high cost, scale and high social significance of road construction. At the same time, most scientists confirm the increasing role of public-private cooperation in such important areas as health and education; this suggests that in the near future, social projects will take a leading position $[5,6]$.

\section{METHODOLOGY}

The first group of problems is related to the legal regulation of public-private partnerships. Since such a partnership can have a variety of legal forms, each of which is regulated in a special way and by a separate law, there is often a need to create a single legal act that will unify the main aspects of cooperation between the state and private business. It should be noted that even in developed countries (the United States, great Britain), where such projects have existed for centuries, there is no concept of "national (Federal) law on public-private partnerships" - all relations are regulated by contracts and historically established rules $[7,8]$.

In Russia, where the experience of public-private partnerships (in particular, concessions) was used for a short time before the revolution and in the modern market economy, starting in the 2000s., of course, there is a need to develop and adopt a number of draft laws that will streamline existing rules and regulations, as well as actively attract private foreign investment to the Russian economy. The main task facing the legislature today is to determine how appropriate it will be to adopt the law, and how to make it as simple and effective as possible [9].

The second group of problems is related to the methodology for developing and implementing publicprivate partnership projects, in particular, evaluating the effectiveness of projects. Many scientific researches and practical works of famous foreign and domestic scientists are devoted to these issues, such as: V. Berens, I. A.
Blank, R. Brayley, P. L. Vilensky, A. Damodaran, V. N. Livshits, S. Myers, S. A. Smolyak, P. Havranek, V. A Chernov, F. Sharpe, Y. V. Yakovets, etc. However, there are no clear recommendations for managing the mechanism for implementing PPP projects $[10,11]$.

For a more in-depth description of PPPs, first of all, the range of problems that arise in the process of implementing PPP projects should be considered. To justify the choice of the form of project implementation and to justify the financing scheme, it is necessary to conduct a detailed expert analysis of incoming proposals, evaluate them according to a number of criteria, and only then make a decision on the use of a particular mechanism for project implementation. To evaluate the project, two main tasks are solved. First, when developing an investment project, it is necessary to identify the composition of factors that affect the implementation of this particular project and determine the list of restrictions that correspond to this PPP project. Secondly, due to the serious scale of PPP projects and a fairly long implementation period, it is necessary to justify the benefits of implementing this project in the socioeconomic sphere. Among the limitations that are considered in the decision-making process on the feasibility of implementing PPP projects, priority is given to quantitative ones.

In addition to the main requirement that the parties to a PPP are the state and private business, there are a number of additional, no less important conditions:

1. the Interaction of the parties in the partnership should be fixed on a legislative basis (agreements, contracts, contracts, etc.);

2. the Interaction of these parties must have a truly partner-like, equal character (i.e., there must be parity, balance of both parties);

3. All the results achieved in the PPP, as well as the costs and risks incurred, are distributed among the participants in the shares fixed in the relevant agreements and contracts.

In addition, the experience of implementing public-private partnerships in different countries of the world has allowed us to formulate a number of principles that determine the viability and feasibility of projects.

These include:

- the principle of observing the public interest through the implementation of socially significant projects in the conditions of observing the commercial interests of all partners;

- adhering to regulatory or project construction period and, as a consequence, the fulfilment of the payback period of the investment, the established repayment period of the borrowed funds, the terms of the partnerships as a whole. This, in turn, determines the development and implementation of innovative tools, methods of control and assessment of the degree of responsibility;

- the principle of establishing a mechanism for the redistribution of ownership rights, the procedure for 
calculating between participants, and the division of responsibility and risks at all stages of the partnership;

In this regard, each PPP project has signs of innovation and is aimed at solving socio-economic problems.

Among the forms of public-private cooperation are:

- contracts related to the provision of service (technical) services for the development and implementation of software, as a rule, they are carried out within 1-3 years for the remuneration specified in the contract;

- contracts related to the transfer of management functions, their duration is from 3 to 8 years or more (for example, management functions during crisis situations). The contracts specify remuneration for the services of the management company;

- contracts related to the lease or temporary transfer of property rights, the duration of such contracts is 8 years or more. Contractual obligations provide for all proceeds from consumers to the performer, and the performer transfers the rent to the state. Under the terms of such contracts, as a rule, the contractor is responsible for the repair, maintenance of objects and, in special cases, investment in real estate under lease ;

- contracts related to concession agreements with the longest duration of up to 30 years. The corresponding agreement sets the amount of payments to the state by the performer, and the main financial flows go through the performer. Its responsibilities extend to full maintenance and investment of facilities;

- contracts related to the management of joint capital, where according to the civil code of the Russian Federation all income is distributed in proportion to participation.

Summing up the review of the forms of cooperation between the state and private business, it should be noted that in world practice today in the lead concession, and in the second place in popularity and prevalence - joint venture [12].

This may be due to the degree of freedom and the nature of the rights to state property that private investors receive. For example, by participating in concession agreements or becoming a shareholder in a joint venture, a private investor receives state property for use with some restrictions. In other words, the closer the right to an object is to the right of ownership, the more attractive it becomes for the investor [13].

Secondly, the role of the state and state regulation in the Russian economy is still very important. This is reflected both in the massive injection of money into the economy, and in the nature of the state's participation in major projects and corporations. This is due to the fact that our country has poorly developed mechanisms for contractual regulation of relations between participants in publicprivate partnerships, and the experience of concession agreements is not widely used. If we conduct a comparative analysis of the forms of implementation of public-private partnerships in Russia and the world, we can say that in the Russian economy, the vast majority of joint projects are carried out on the initiative and with significant state participation through Federal and regional target programs, investment funds, banking structures, concession agreements, regional development corporations, special economic zones and technology parks, etc. $[14,15]$.

The effectiveness of participation in the project is determined in order to check the feasibility of the investment project and the interest of all its participants in it. For the validity of such calculations, criteria are formed for selecting projects from among those who have applied for the possibility of joint participation. Depending on the direction and complexity of projects, the set of criteria to be formed may vary from the cost of the project and the forms of investment to the level of possible sources of financing and implementation of such projects. Quantitative and qualitative limitations must also be taken into account, which have an impact depending on the established rank and priority of the implemented program or project on the further operation of the object with the condition of reasonable social efficiency. In this case, the partnership documents must include the conclusions of investment consulting companies. These criteria mainly affect the observance of public interests. As for representatives of private businesses, in this case, along with the established criteria, another one is added that characterizes the profitability of the project in which they participate. Close attention should be paid to the formation of the process of allocating and receiving budget funds during the entire period of implementation of the joint project.

The effectiveness of participation in the project includes such types of efficiency as profitability for participating enterprises, the effectiveness of investment in shares, and the productivity of participation in the project of higherlevel structures.

The profitability of the project from the point of view of the enterprises participating in the project is characterized by indicators of the effectiveness of their participation in relation to joint - stock companies and indicators of return on equity. The method of calculating the effectiveness of the company's participation in the project is much the same as calculating the effectiveness of the project as a whole (public and commercial efficiency). However, in this case, first of all, attention is paid to the financial flows of a particular enterprise - a participant in the project, and, secondly, the composition of financial flows is adjusted. Here, as part of the estimated performance indicators, the cash flow that characterizes the receipt and repayment of loans should be included in the calculation. Financial flows that take into account the movement of own funds and dividend payments are not taken into account in this scheme [16-18]

When evaluating investments in shares, the calculation of the project's effectiveness for shareholders can be carried out when the company's dividend policy is determined. The valuation is usually performed using one of two methods - the balance sheet method or the cash flow method. 
The use of the efficiency calculation tools described above is largely determined by the main principles for evaluating the effectiveness of investment projects, which include:

- monitoring of emerging project deviations throughout the entire billing period;

- information modeling of the financing process, illustrating all possible actions with funds for the billing period;

- the need for similarity when comparing different projects(project variants);

- the principle of validity of project decisions and maximization of the resulting effect for potential investors. It is obvious that the investor's interest is in an unconditional benefit, and not necessarily expressed in an increment of funds, and as a result, when choosing the most suitable project for investment, preference is given to the project with the highest value of the effect;

- the need and obligation to take into account the time factor. Projects implemented in partnership with the state usually have a long implementation period. In this regard it is necessary to take into account the duration turnover of invested funds and changes in their cost in the process of implementing projects and reaching their design capacity; - the account of indicators of costs and revenues. When justifying the effectiveness of projects, attention should be focused on costs and revenues that take into account the use of existing production assets, as well as possible losses from temporary or partial shutdown of existing production.

- consideration of possible economic and non-economic significant consequences of the project that occur during its implementation and subsequent operation;

- the need for a well-thought-out balanced policy to provide all project participants with equal conditions based on specific interests and different estimates of the cost of their capital;

- mandatory accounting for the impact of inflation, which is important when implementing projects with a long implementation period;

- use of risk management mechanisms in project implementation management.

Due to the fact that the methodology for evaluating the effectiveness of investment projects is based on discounting methods, management decisions do not take into account the ability to adjust the project implementation process in the course of its implementation, to identify and minimize the company's losses in a timely manner. For example, during the life of a project, especially if it is medium - or long-term, management decisions can be made that significantly affect the capital structure of the company, the project, the cost of assets and their profitability [19, 20].

Therefore, in the modern theory of investment, the direction of evaluating the effectiveness of investment projects is becoming more and more developed, improving the traditional methods of discounting cash flows. This direction is based on the use of the real options method in evaluating the effectiveness of an investment project.

The socio-economic significance of joint projects can be determined on the basis of an integrated assessment by analyzing the comparison of project costs and expected benefits as a result of project implementation. The purpose of this analysis is to justify the feasibility of implementing a project from the point of view of social development by simply adding the cost and benefit values with the appropriate mathematical signs, taking into account the time factor discount. This approach is based on forecasting the economic impact on the project throughout its life cycle. This approach can use traditional techniques for calculating indicators that characterize the economic efficiency of PPP projects. The procedure for calculating the profitability of the project is a clear indicator that allows you to argue for the effectiveness of the project. This approach, in contrast to other financial assessment techniques, is characterized by the ability to take into account external factors in the calculation, including the occurrence of price distortions, which, in turn, allows you to quickly adjust the project parameters. In addition, this approach can quickly respond to market changes.

The result of evaluating the options under consideration when filling the investment program with PPP projects is the ranking of projects based on established criteria, and the identification of priority projects recommended for implementation. Moreover, this may not necessarily be an effective project from the point of view of investment, it may have a number of restrictions that will not allow it to be included in the implementation program. This selection mechanism allows you to set the optimal order of implementation of projects included in the investment program. By analyzing projects based on the selected criteria and determining restrictions, an evidence base is created for the formation of an investment portfolio. Expert decision-making models are used to make the final decision on evaluating the priority (ranking) of projects, in particular, a multi-factor model for evaluating the project on a point basis. This model is more accurate and correct, because it uses a certain gradation of the quality of each specific factor, which acts as a criterion or restriction. The model generates a final list of General and specific evaluation indicators, each of which gets its own value of the weighting coefficient of significance [21, 22].

\section{DISCUSSION}

From our point of view, the algorithm for evaluating PPP projects using real options should be more detailed and extensive. This can be argued by the fact that the main purpose of using real options in long - term projects is to reduce risk and uncertainty, so the correct choice and classification of options, determining the optimal timing of its implementation, cost and probability characteristics directly affects the level of risk of the project. Including 
options in a project, especially if it is a long-term publicprivate partnership project, it is necessary not only to determine their cost, but also to provide for a full range of measures to ensure their timely implementation, the sources of additional funds raised, and the accounting of results. Developing these positions further, we can put forward two hypotheses $[3,5]$.

The first is related to the fact that when including options in investment projects, it is necessary to provide a mechanism for managing options, which includes managing the main parameters of options (timing, cost), as well as a decision-making system. Together, the mechanisms for managing options and their parameters should become an options management system.

The second hypothesis is a continuation of the first one and is based on the fact that the real options management system of the investment project, by analogy with the risk management system, can exist quite independently. At the same time, the performance indicators of the investment project, such as BDD, GNI, and ID, will simply be adjusted by the value of the options.

\section{RESULTS}

Let's consider an algorithm for evaluating a project that contains real options.

There are a wide variety of options available, and they can be classified on different grounds.

The classification options on indicators such as deadlines, cost, form of implementation, in General, highly conditional and are formalized - in fact, about time, cost, and performance are characteristics of the option, without any of them it just does not make sense. Therefore, when talking about an option, usually use, for example, the following terminology - "European put/call option for a year or American call/put option for a year".

A real option allows you to make alternative management decisions related to the functioning of the company based on indicative methods. In contrast to financial options used when buying or selling securities described above, real options are applicable to real assets, such as buildings, structures, real estate, machines, mechanisms [23].

Many investment projects contain various types of options. For example, a company is considering purchasing a license to develop an oil field on a specific piece of land. But at the moment, the cost of oil production in this place will not be recouped by revenues from its implementation, so such a project looks unprofitable. On the other hand, given that oil prices on the world market are subject to serious fluctuations, it is not difficult to assume that in a year or two they will rise sharply and the development of the field will bring significant profits. In this case, the license to develop oil gives the company the right, but not the obligation, to implement the project, if the conditions are favorable for this. In other words, by purchasing a license, the company acquires a real option.

Real options are very diverse, and, in General, the formation of new types of options is not limited. However, you should take into account the fact that any option, especially a real one, must, like a financial one, have its own characteristics. In addition, if financial options clearly indicate a buy or sell ("put" or "call"), then real options give rise to a very wide range of rights for their owners. There are several options for classifying real options based on various characteristics: by action, by type of uncertainty, by complexity, and by the side of the balance sheet. In our opinion, it is most appropriate to use the classification by action-the opportunity created by a real option.

The considered method of real options makes it possible to evaluate the effectiveness of investment projects to respond to possible changes in conditions throughout the implementation period.

In addition, analysis using real options is used in the case of considering real estate investments and making decisions on the development of companies. The main element of using options valuation in this case is forecasting future development options [24].

The feasibility of using the real options method in evaluating PPP investment projects is limited by a number of conditions. Due to the fact that long-term projects are always subject to a high degree of uncertainty, the project team should be able to make prompt and flexible management decisions when new project data becomes available. The fulfillment of this condition ultimately affects the financial result of the project.

Here we should focus on the fact that when evaluating investment projects, the traditional method calculates the financial result, which is undoubtedly important and necessary, but projects implemented on PPP terms, as already noted, need additional features and functions that accompany the adoption of sound management decisions. This approach increases the interest of potential private investors in implementing joint projects and programs with the state.

The use of the real options method provides important advantages in the implementation of the project.

First of all, it is variability and flexibility in decisionmaking. The mechanism of public-private partnership requires a flexible and rapid response to changing external and internal conditions that arise in the project environment.

A comprehensive approach to evaluating PPP investment projects. In contrast to the discounted cash flow method, which takes into account only the receipt and expenditure of funds, the proposed integrated approach allows you to take into account a greater number of factors, such as setting deadlines for joining PPP projects, forecasting future revenues, accounting for possible losses during the implementation of PPP projects and the timing of investment turnover [25]. 


\section{CONCLUSION}

The article presents a comprehensive analysis and assessment of legal, organizational, and methodological problems of implementing public-private partnership in Russia and abroad. As a result of the analysis, problems of different levels are formulated and ways to solve them are proposed.

The problems of the first level include the harmonization of legal norms between different countries and the creation of a unified international legal environment for the implementation of such projects. The existing legislation, which addresses issues of public-private partnership, does not sufficiently consider all possible forms and contradictions that arise in the process of concluding contracts and partnership agreements between participants in projects implemented under PPP conditions.

The second level of problems can be defined as organizational and managerial, related to the procedures for making managerial decisions in the framework of public-private projects by both public authorities and private structures. From the definition of public-private partnership, it follows that the cooperation between the state and the private investor can be medium - and longterm, that is, the actual period of existence of the partnership is from 2-3 to 30-40 years. This suggests that during the period of its existence, such partnerships affects not only the interests of the state and specific private investor, but credit and banking institutions (which lend to private business), companies, other businesses (e.g., manufacturers of equipment, raw materials). All of them, to some extent, are participants (direct or indirect) in public-private partnerships, so at this level, mechanisms should be developed that take into account:

- public significance of the project;

- compliance with the regulatory construction deadlines, strict compliance with the terms of repayment of borrowed funds, return on investment and innovation, partnership in General, which involves the development and implementation of tools for control and responsibility);

- redistribution of ownership rights, calculation algorithm between the parties, and algorithm for sharing responsibility and risks at all stages of the partnership.

In other words, at this level, methodological recommendations should be developed that regulate the relationship between the state and private business within the legal space that will be formed after solving the problems of the first level.

Finally, the third level of problems is methodological. This should include problems that arise in the economic and mathematical apparatus used when working on public-private projects. Analysis of many implemented projects suggests that traditional approaches to investment project management, mainly applied to PPP projects, are not effective enough. Analytical studies suggest that traditional methods of evaluating the effectiveness of investment projects do not fully consider the full range of factors and opportunities for rapid response to emerging crisis phenomena.

This should be considered especially for projects with a long implementation period. Because it is for such projects that it is necessary to adjust the discount rate during implementation, consider the possibility of expanding the project or partially changing it, transferring ownership rights, and finally, abandoning the project. To reduce the degree of uncertainty and risk, as well as to slightly improve the calculations of the effectiveness of public-private partnership projects, it is possible to use the real options method, which takes into account the ability of management to flexibly influence the course of the project and make management decisions that significantly change the cost of the project.

\section{REFERENCES}

[1] Public-Private Partnerships. Reference Guide. Version 2.0. International Bank for Reconstruction and Development, 2014.

[2] National projects: key goals and expected results, 2019, Available at: http://government.ru/projects/selection/741/35675.

[3] Justification of the effectiveness of PPP mechanisms, Expert release, 2017, Available at: http://www.pppi.ru.

[4] Public-private partnership market in Russia: problems and prospects of development, 2016, Available at: http://iptg.ru/IPT.pdf.

[5] D. Jeffrey, Creating a framework for publicprivate partnership programs: a practical guide for decision makers, Electronic Journal, 2015, Available at:

https://openknowledge.worldbank.org/handle/10986/22 822.

[6] Examples of public-private partnership (PPP) projects, 2015, Available at:

https://planningtank.com/economics/public-privatepartnership-ppp-projects.

[7] R.J. Armando, E.M. Ivan, Public Private Partnerships in the USA, 2019, Available at: https://www.lexology.com/library/detail.aspx?g=d1d18 35b-849e-4ded-87a6-fd79b0fc6d54.

[8] F. Guido, Hai Di, Th. Obermay, Public Private Partnerships in the EU: Widespread shortcomings and limited benefits, 2018, Available at: 
https://www.eca.europa.eu/Lists/ECADocuments/SR18 _09/SR_PPP_EN.pdf.

[9] G. Marievic, R. Anonuevo, B. Ashkin, M. Beynsberger, B. Werneck, M. Saadi, Public-Private Partnership Law Review, Third Edition, 2017.

[10] A. Stulginskis, V. Leknevicien, Valuation of Public Projects for Regional Development: Critical Approch, Economics and Rural Development, Aleksandras Stulginskis University 10(2) 2014 16-24. DOI: http://dx.doi.org/10.15544/erd.2014.008

[11] Public-private partnership, 2018, Available at: https://en.wikipedia.org/wiki/Publicprivate_partnership.

[12] S. Gray, J. Hall, G. Pollard, The public private partnership paradox, UQ Business School, University of Queensland. Australia, 2018.

[13] S.A. Baronin, N.V. Bredikhina, S.A. Bizhanov, A.G. Yankov, Managing the total cost of ownership in real estate lifecycle contracts as a promising tool for energy efficiency development in the housing industry, Economy. Sociology. Management 2 (2018) 78-82.

[14] E.R. Yescombe, E. Farquharson, Public-Private Partnerships for Infrastructure, 2nd Edition, 2018.

[15] Recommendations for the implementation of public-private partnership projects in the subjects of the Russian Federation, Association "center for PPP development", 2013.

[16] M. Kachanovska, Methods of data analysis: analysis of "cost-benefit" analysis of "costeffectiveness", su - HSE, 2006.

[17] Methodological recommendations for evaluating the effectiveness of investment projects, 3rd ed., ISPR, Ekonomika, 2008.

[18] Order of the Ministry of economic development of the Russian Federation from 30.11.2015, No 894, 2015, Available at: http://www.consultant.ru/document/cons_doc_LAW_1 92148/.

[19] Order of the Ministry of economic development of the Russian Federation dated 24.02.2009, No 58 (as amended on 02/05/2018), 2018, Available at: http://www.consultant.ru/document/cons_doc_LAW_8 $7435 /$.
[20] Order of the Ministry of economic development of the Russian Federation from 14.12.2013, № 741, 2013, Available at:

http://www.consultant.ru/document/cons_doc_LAW_1 60381/.

[21] A.A. Kuznetsov, The Mechanism of a substantiation of organizational forms of realization of investment projects of road construction, Thesis for the degree of Candidate of Philological Sciences, 2019.

[22] Decree of the Government of the Russian Federation of 01.03.2008, No 134 (as amended on 12/23/2016), 2016, Available at: http://www.consultant.ru/document/cons_doc_LAW_7 $5354 /$.

[23] Decree of the Government of the Russian Federation of 14.12.2010, No 1016 (as amended on 06/07/2017), 2016, Available at:

http://www.consultant.ru/document/cons_doc_LAW_1 08319/.

[24] N.A. Moiseenko, O.I. Timoshina, Key issues in selecting a public-private partnership (PPP) project, Theoretical and scientific-methodical journal Bulletin of the University 13 (2013) 80-86.

[25] N. Moiseenko, Specifics of applying mechanisms of public-private partnership when selecting investment projects, Internationl Scientific Siberian Transport Forum "TransSibtria 2018", MATEC Web of Conference, 2018. 